\title{
Halothane does not protect against vascular injury in isolated cerebral and mesenteric arteries
}

\author{
[L’halothane ne protège pas contre les lésions vasculaires dans des artères cérébrales \\ et mésentériques isolées]
}

Koji Ogawa MD, Yasuyuki Tokinaga MD, Shizue Iwahashi MD, Kazuhiro Mizumoto MD, Yoshio Hatano MD

Purpose: This study was designed to examine regional differences in the vascular injury induced by hydrogen peroxide $\left(\mathrm{H}_{2} \mathrm{O}_{2}\right)$, and to determine its modulation by halothane in canine basilar and mesenteric arteries.

Methods: Rings of canine basilar and mesenteric arteries with intact endothelium were mounted in Krebs bicarbonate solution for isometric tension recording. The relaxation responses to substance $\mathrm{P}\left(10^{-8} \mathrm{M}\right)$ and sodium nitroprusside (SNP; $10^{-8}$ to $\left.10^{-5} \mathrm{M}\right)$ were examined before and after exposure to $\mathrm{H}_{2} \mathrm{O}_{2}(\mathrm{I}$ $\mathrm{mM}$ ) for eight minutes in the presence or absence of halothane (2\%), to evaluate the effects of oxidative injury on the endothelium-dependent and -independent relaxation. The contractile responses to $\mathrm{KCl}(30 \mathrm{mM})$ and prostaglandin $(\mathrm{PG}) \mathrm{F}_{2 \alpha}\left(3 \times 10^{-6}\right.$ $\mathrm{M})$ were also compared in rings with and without exposure to $\mathrm{H}_{2} \mathrm{O}_{2}$.

Results: After exposure to $\mathrm{H}_{2} \mathrm{O}_{2}$, the relaxant responses to substance $P$ were significantly inhibited in basilar arteries $(P<$ $0.0 \mathrm{I})$, but not in mesenteric arteries. Exposure to $\mathrm{H}_{2} \mathrm{O}_{2}$ also attenuated SNP-induced relaxation in basilar $(P<0.05)$, but not in mesenteric arteries. The attenuation of the contractile responses to $\mathrm{KCl}$ and $\mathrm{PGF}_{2 \alpha}$ after $\mathrm{H}_{2} \mathrm{O}_{2}$ exposure was observed only in basilar arteries $(P<0.0 \mathrm{I})$. Simultaneous exposure to halothane did not affect the attenuation of these relaxant and contractile responses. Scanning electron microscopy revealed that $\mathrm{H}_{2} \mathrm{O}_{2}$ resulted in marked disruption of the endothelial layer in basilar arteries, compared to almost no morphological changes in mesenteric arteries.

Conclusion: These results indicate that the endothelium and vascular smooth muscle of the basilar artery are more susceptible to oxidative stress than those of the mesenteric artery. Halothane, at clinically relevant concentrations, exerts no significant influence on this vascular injury.
Objectif : Vérifier les différences régionales des lésions vasculaires induites par le peroxyde d'hydrogène $\left(\mathrm{H}_{2} \mathrm{O}_{2}\right)$ et déterminer leur modulation par l'halothane dans des artères basilaires et mésentériques canines.

Méthode: Des anneaux d'artères basilaires et mésentériques canines, comportant un endothélium intact, ont été montés dans une solution bicarbonate de Krebs pour l'enregistrement de la tension isométrique. La réaction de relâchement à la substance $P$ $\left(10^{-8} \mathrm{M}\right)$ et au nitroprussiate de sodium (NPS ; $10^{-8}$ à $\left.10^{-5} \mathrm{M}\right)$ a été examinée avant et après l'exposition à $\mathrm{H}_{2} \mathrm{O}_{2}(\mathrm{I} \mathrm{mM})$ pendant huit minutes en présence ou non d'halothane à $2 \%$ pour évaluer les effets de la lésion oxydative sur le relâchement dépendant ou non de l'endothélium. Les réactions contractiles au $\mathrm{KCl}(30 \mathrm{mM})$ et à la prostaglandine $(P G) F_{2 \alpha}\left(3 \times 10^{-6} \mathrm{M}\right)$ ont été aussi comparées dans des anneaux exposés ou non à $\mathrm{H}_{2} \mathrm{O}_{2}$.

Résultats : Après l'exposition à $\mathrm{H}_{2} \mathrm{O}_{2}$, les réactions de relâchement à la substance $P$ ont été significativement inhibées dans les artères basilaires $(P<0,0 I)$, non dans les mésentériques. L'exposition à $\mathrm{H}_{2} \mathrm{O}_{2}$ a aussi diminué le relâchement induit par le NPS dans les artères basilaires $(P<0,05)$ seulement. L'atténuation des réactions contractiles au $\mathrm{KCl}$ et à la $\mathrm{PGF}_{2 \alpha}$ après l'exposition à $\mathrm{H}_{2} \mathrm{O}_{2}$ $a$ été observée seulement dans les artères basilaires $(P<0,0 I)$. L'exposition simultanée à l'halothane n'a pas modifié la baisse de ces réactions de relâchement et de contraction. L'examen au microscope électronique à balayage a révélé que $\mathrm{H}_{2} \mathrm{O}_{2}$ a provoqué une rupture marquée de la couche endothéliale des artères basilaires, comparativement à la quasi-absence de changements morphologiques dans les artères mésentériques.

Conclusion : L'endothélium et les muscles lisses de l'artère basilaire sont plus sensibles au stress oxydatif que ceux de l'artère mésentérique. L'halothane, en concentrations cliniquement significatives, n'exerce pas d'influence sensible sur cette lésion vasculaire.

From the Department of Anesthesiology, Wakayama Medical University, Wakayama, Japan.

Address correspondence to: Dr. Koji Ogawa, Department of Anesthesiology, Wakayama Medical University, 811-1 Kimiidera, Wakayamacity, Wakayama, 641-0012, Japan. Phone: +81-73-441-0611; Fax: +81-73-448-1032; E-mail: ogawak@wakayama-med.ac.jp

Funding sources: Financial support was provided solely from departmental and institutional sources.

Accepted for publication March 22, 2005.

Revision accepted April 29, 2005. 


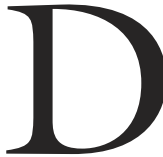
ETERMINATION of the effects of anesthetics on oxygen radical-induced vascular injury may provide information to better understand ischemia-reperfusion injury during anesthesia. Volatile anesthetics, including halothane, have been reported to modify the endothelial cell injury induced by hydrogen peroxide $\left(\mathrm{H}_{2} \mathrm{O}_{2}\right) \cdot{ }^{1,2} \mathrm{H}_{2} \mathrm{O}_{2}$ is one of the major reactive oxygen species involved in oxidative stress-induced vascular injuries. ${ }^{3,4} \mathrm{H}_{2} \mathrm{O}_{2}$, administered exogenously ${ }^{5-9}$ and released from activated neutrophils, ${ }^{10,11}$ has been demonstrated experimentally to induce functional and morphological alterations in both endothelial and vascular smooth muscle cells.

Reactive oxygen species have been implicated in inducing vascular damage during post-ischemic reperfusion. ${ }^{12,13}$ Although these radicals are well documented as causing vascular endothelial cell injury that results in organ dysfunction and damage, the endothelial dysfunction and injury seem to exhibit large variability. ${ }^{14-17}$ Some vessels were relatively unaffected, whereas others were damaged irreversibly. The endothelium and underlying vascular smooth muscle of the cerebral artery are recognized to exhibit heterogeneous functional and histological properties compared with those of other extracerebral arteries. ${ }^{18-20}$ However, little information is available regarding the differences in response to oxidative injury between cerebral and extracerebral arteries, and how inhaled anesthetics might differentially modify these responses.

The first goal of the present in vitro study was to investigate and compare the pharmacological and morphological differences in the endothelial and vascular smooth muscle injuries induced by $\mathrm{H}_{2} \mathrm{O}_{2}$ in isolated dog basilar and mesenteric arteries. The second goal was to determine whether halothane can modulate $\mathrm{H}_{2} \mathrm{O}_{2}$-induced vascular injury in both cerebral and extracerebral arteries.

\section{Materials and methods}

All experimental procedures and protocols were approved by the Animal Use Committee at Wakayama Medical University.

\section{Preparation of basilar and mesenteric arteries}

Ten adult male $(n=7)$ and female $(n=3)$ mongrel dogs weighing 10 to $18 \mathrm{~kg}$ (12-24 months old) were anesthetized with iv ketamine $\left(10 \mathrm{mg} \cdot \mathrm{kg}^{-1}\right)$, and then killed by bleeding from the common carotid arteries. After craniotomy and laparotomy, the brain and mesentery were rapidly removed. Basilar and mesenteric arteries of similar external diameter $(0.8-1.0 \mathrm{~mm})$ were carefully dissected and immersed in cold Krebs bicarbonate solution (composed of $118.2 \mathrm{mM} \mathrm{NaCl}$,

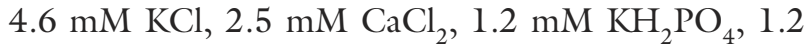
$\mathrm{mM} \mathrm{MgSO}_{4}, 24.8 \mathrm{mM} \mathrm{NaHCO}_{3}$ and $10 \mathrm{mM}$ dextrose). The arteries were cleaned of surrounding tissues and cut into ring segments $3 \mathrm{~mm}$ in length, with care taken not to damage the endothelium. The integrity of the endothelium was later confirmed by assessing the vasorelaxant responses to substance $\mathrm{P}\left(10^{-8} \mathrm{M}\right){ }^{21}$

\section{Isometric tension experiment}

Arterial rings with an intact endothelium were mounted vertically between two stainless steel hooks in organ baths $(10 \mathrm{~mL}$ capacity) filled with Krebs bicarbonate solution $\left(37^{\circ} \mathrm{C}\right)$, which was aerated with a mixture of $5 \%$ carbon dioxide and $95 \%$ oxygen. One of the hooks was anchored and the other was connected to a force transducer (Nihondenki San-Ei Co., Tokyo, Japan). Changes in isometric force were amplified and displayed on a chart recorder (Nihondenki San-Ei Co., Tokyo, Japan). Optimal resting tension was adjusted to $2.0 \mathrm{~g}$ in both arteries, which was the minimum amount of stretch necessary to achieve the maximal contractile response to $30 \mathrm{mM} \mathrm{KCl}$, as determined in a preliminary investigation. Before the start of the experiment, the arterial rings were allowed to equilibrate for 60 min, during which time the bathing solution was replaced every 15 min.

\section{Experimental protocols}

Submaximal contraction of both arteries in response to $30 \mathrm{mM} \mathrm{KCl}$ was evaluated initially, and the preparations were washed with fresh bathing solution at least three times.

First, the maximal substance $\mathrm{P}$-induced relaxation was examined, before and after exposure to $\mathrm{H}_{2} \mathrm{O}_{2}$, to evaluate the effects of the oxidative insult on the endothelium-dependent relaxation. Prostaglandin $(\mathrm{PG}) \mathrm{F}_{2 \alpha}$ $\left(3 \times 10^{-6} \mathrm{M}\right)$ was used to attain submaximal contraction of the basilar and mesenteric arteries. After a plateau was reached, substance $\mathrm{P}\left(10^{-8} \mathrm{M}\right)$ was added to ascertain the maximal relaxation. Each ring, except for the control ring, was exposed to $\mathrm{H}_{2} \mathrm{O}_{2}(1 \mathrm{mM})$ for eight minutes in the presence or absence of halothane $(2 \%)$, and then washed repeatedly with fresh bathing solution for 30 min to wash $\mathrm{H}_{2} \mathrm{O}_{2}$ and/or halothane from the organ bath. Thirty minutes after exposure to $\mathrm{H}_{2} \mathrm{O}_{2}$, the relaxant responses of $\mathrm{PGF}_{2 \alpha}$-precontracted rings to substance $\mathrm{P}$ were again obtained. The relaxation responses to substance $\mathrm{P}$ in rings exposed to $\mathrm{H}_{2} \mathrm{O}_{2}$ were compared to those in unexposed (control) basilar and mesenteric arteries. Functional endothelial injury caused by $\mathrm{H}_{2} \mathrm{O}_{2}$ was evaluated by attenuation of the relaxant responses to substance P. 
Secondly, the relaxation responses to sodium nitroprusside (SNP; $10^{-8}$ to $10^{-5} \mathrm{M}$ ) were investigated to evaluate the effects of oxidative stress on endothelium-independent relaxation. Similar to the first experiment, the relaxation responses to SNP in rings with and without eight-minute exposure to $\mathrm{H}_{2} \mathrm{O}_{2}$ were compared in both arteries. The relaxation responses to substance P and SNP were expressed as the percentage relaxation of the precontraction induced by $\mathrm{PGF}_{2 \alpha}$. One hundred percent relaxation indicates complete reversal of the precontraction.

Thirdly, the contractile responses to $\mathrm{KCl}(30 \mathrm{mM})$ and $\mathrm{PGF}_{2 \alpha}\left(3 \times 10^{-6} \mathrm{M}\right)$ were also examined. The contractile responses to each vasoconstrictor in rings with and without exposure to $\mathrm{H}_{2} \mathrm{O}_{2}$ were compared and expressed as a percent relative to those obtained before exposure.

\section{Scanning electron microscopy}

In order to evaluate the endothelial cell injury morphologically, basilar and mesenteric arteries cut lengthwise with a razor blade were exposed to $1 \mathrm{mM} \mathrm{H}_{2} \mathrm{O}_{2}$ for eight minutes in the presence or absence of $2 \%$ halothane. Some rings were exposed to Krebs bicarbonate solution, without $\mathrm{H}_{2} \mathrm{O}_{2}$ or halothane, as controls. After vigorous washing with fresh bathing solution for $30 \mathrm{~min}$, the arterial preparations were fixed overnight in $2 \%$ glutaraldehyde in $0.1 \mathrm{M}$ phosphate buffer $(\mathrm{pH}$ 7.4). After washing in phosphate buffer, the tissues were dehydrated in a graded ethanol series, criticalpoint-dried, and coated with gold in an ion sputtercoating system (JFC-1100, JEOL, Tokyo, Japan). All specimens were examined using a JSM-T220 scanning electron microscope (JEOL, Tokyo, Japan) at a magnification ratio of 2000 .

\section{Drugs and solutions}

All drugs were of highest purity commercially available: hydrogen peroxide, SNP (Sigma Chemical, St. Louis, MO, USA), substance P (Protein Research Foundation, Osaka, Japan) and halothane (Takeda Pharmaceutical Co., Tokyo, Japan). Halothane was delivered by a calibrated vaporizer (Fluotec 3, Ohmeda, Steeton, UK) to provide the appropriate concentrations in the gas mixture aerating the bathing solution. The concentrations in the resulting gas mixture were measured and adjusted using an Atom 303 anesthetic gas monitor (Atom, Tokyo, Japan). Drug concentrations are expressed as the final concentration in the organ bath. All drugs except halothane were dissolved in distilled water and added directly to the organ bath in a volume of $100 \mu \mathrm{L}$ or less.

\section{Statistical analysis}

All data were expressed as mean $\pm S E M$; $n$ refers to the number of the dogs from which basilar and mesenteric arterial rings were taken. Statistical analyses were performed using Student $t$ test for unpaired comparisons. When more than two means were compared, one-way analysis of variance with Scheffe's post-hoc F test was used. $P$-values less than 0.05 were considered significant.

\section{Results}

Effects of $\mathrm{H}_{2} \mathrm{O}_{2}$ exposure on substance P-induced endothelium-dependent vasorelaxation

The relaxations induced by substance $\mathrm{P}\left(10^{-8} \mathrm{M}\right)$ in basilar and mesenteric arterial rings that were not exposed to $\mathrm{H}_{2} \mathrm{O}_{2}$ were $69 \pm 5 \%(n=6)$ and $74 \pm 4 \%(n$ $=5$ ) of the precontraction tension, respectively. After exposure to $\mathrm{H}_{2} \mathrm{O}_{2}$, the relaxant responses to substance $\mathrm{P}$ were significantly reduced in basilar arteries $(29 \pm$ $7 \%, n=6, P<0.01)$, but unaffected in mesenteric arteries $(70 \pm 4 \%, n=5)$. Simultaneous exposure to $2 \%$ halothane resulted in no significant modulation of the attenuation of the relaxant responses to substance $\mathrm{P}$ in basilar arteries $(n=6)$, (Figure 1$)$.

\section{Effects of $\mathrm{H}_{2} \mathrm{O}_{2}$ exposure on SNP-induced endothelium- independent vasorelaxation}

SNP induced a concentration-dependent relaxation of basilar and mesenteric arterial rings that was maximal
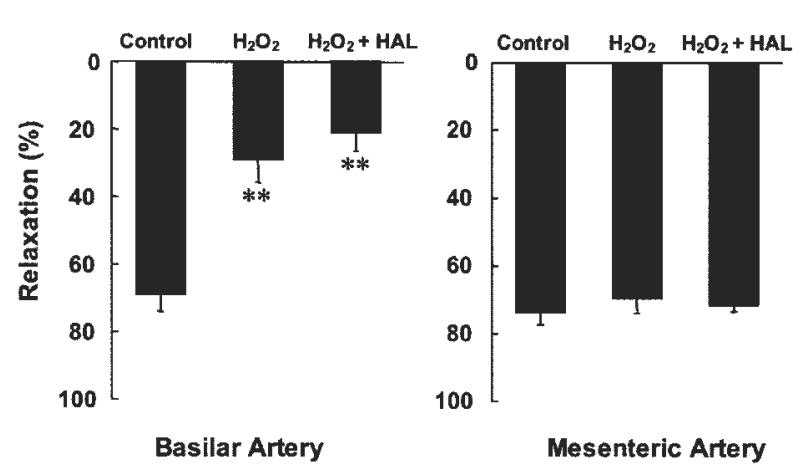

Mesenteric Artery

FIGURE 1 Effects of hydrogen peroxide $\left(\mathrm{H}_{2} \mathrm{O}_{2}, 1 \mathrm{mM}\right)$ exposure on substance $\mathrm{P}\left(10^{-8} \mathrm{M}\right)$-induced endotheliumdependent relaxation in canine basilar (left) and mesenteric (right) arteries. Arterial rings were precontracted with prostaglandin $(\mathrm{PG}) \mathrm{F}_{2 \alpha}\left(3 \times 10^{-6} \mathrm{M}\right)$ and the relaxation responses are expressed as a percentage of the $\mathrm{PGF}_{2 \alpha}$ precontraction. $\mathrm{H}_{2} \mathrm{O}_{2}$ exposure significantly inhibited the relaxant responses to substance $\mathrm{P}$ in basilar arteries, but not in mesenteric arteries $(P<0.01)$. Simultaneous exposure to halothane $(2 \%)$ produced no significant influence on the attenuation of substance $\mathrm{P}$-induced relaxation. ${ }^{*} \mathrm{P}<0.01$ vs control. 


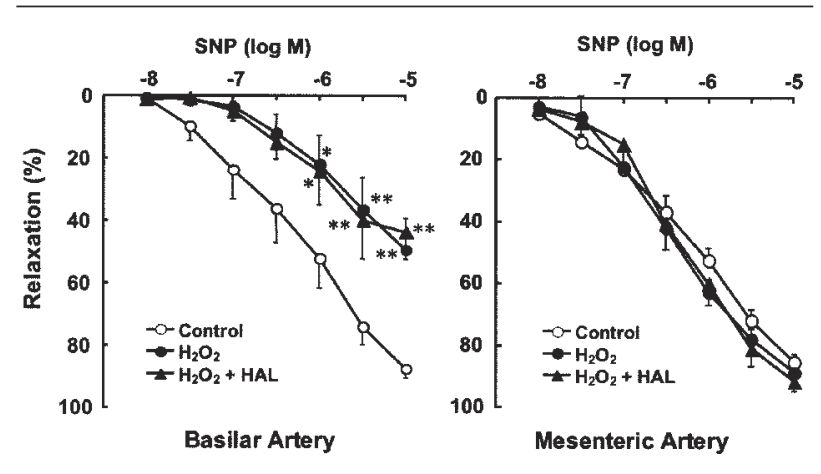

FIGURE 2 Effects of hydrogen peroxide $\left(\mathrm{H}_{2} \mathrm{O}_{2}\right),(1 \mathrm{Mm})$ exposure on the relaxation response to sodium nitroprusside (SNP; $10^{-5}$ to $10^{-8} \mathrm{M}$ ) in canine basilar (left) and mesenteric (right) arteries. Arterial rings were precontracted with prostaglandin $(\mathrm{PG}) \mathrm{F}_{2 \alpha}\left(3 \times 10^{-6} \mathrm{M}\right)$ and relaxation responses are expressed as a percentage of the $\mathrm{PGF}_{2 \alpha}$ precontraction. Exposure to $\mathrm{H}_{2} \mathrm{O}_{2}$ significantly attenuated the relaxant responses to SNP at concentrations of $10^{-6} \mathrm{M}$ and higher in basilar arteries, but not in mesenteric arteries. Simultaneous exposure to halothane $(2 \%)$ produced no further modulation of the attenuation of SNP-induced relaxation. ${ }^{*} P<0.05,{ }^{*} P<0.01$ vs control.

at a concentration of $10^{-5} \mathrm{M}$ in both arteries $[88 \pm 3 \%$ $(n=7)$ and $89 \pm 2 \%(n=6)$ in basilar and mesenteric arteries, respectively]. The relaxant responses to SNP were also attenuated after $\mathrm{H}_{2} \mathrm{O}_{2}$ exposure in basilar arteries $(n=7)$. The relaxation induced by SNP at concentrations of $10^{-6} \mathrm{M}(P<0.05)$ and higher $(P$ $<0.01)$ was significantly inhibited in basilar arteries exposed to $\mathrm{H}_{2} \mathrm{O}_{2}$. By contrast, in mesenteric arteries, the concentration-response curve for SNP was not affected by exposure to $\mathrm{H}_{2} \mathrm{O}_{2}(n=5)$. Halothane did not affect the response to SNP in either artery $(n=4$, each), (Figure 2).

\section{Effects of $\mathrm{H}_{2} \mathrm{O}_{2}$ on the contractile responses to $\mathrm{KCl}$,} phenylephrine or $P G F_{2 \alpha}$.

Figure 3 indicates the effects of $\mathrm{H}_{2} \mathrm{O}_{2}$ exposure on the contractile responses to $\mathrm{KCl}(30 \mathrm{mM})$ and $\mathrm{PGF}_{2 \alpha}$ $\left(3 \times 10^{-6} \mathrm{M}\right)$ in basilar and mesenteric arteries. The contractile responses to $\mathrm{KCl}$ in basilar rings with and without exposure to $\mathrm{H}_{2} \mathrm{O}_{2}$ were $59 \pm 6 \%$ and $114 \pm$ $7 \%$ of the prior control exposures, respectively $(n=$ 7, each). $\mathrm{H}_{2} \mathrm{O}_{2}$ exposure significantly attenuated the contractile responses to $\mathrm{KCl}(n=7, P<0.01)$. The $\mathrm{PGF}_{2 \alpha}$-induced contraction was also attenuated in basilar rings after exposure to $\mathrm{H}_{2} \mathrm{O}_{2}(65 \pm 9 \%, n=7)$ compared to those without exposure $(100 \pm 4 \%, n=$

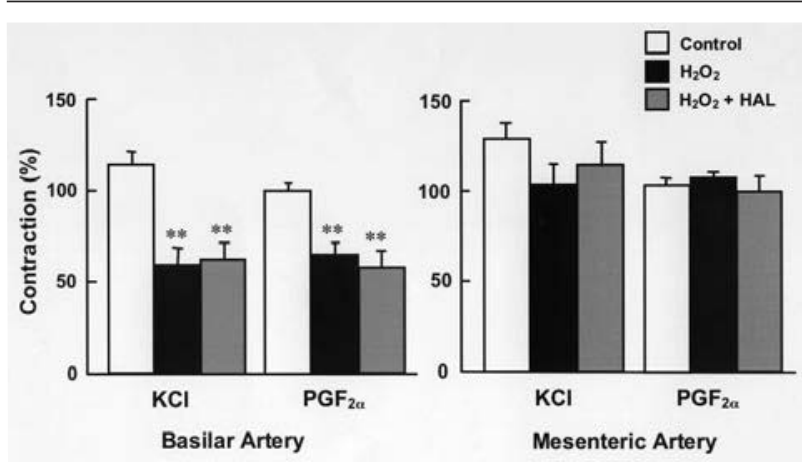

FIGURE 3 Effects of hydrogen peroxide $\left(\mathrm{H}_{2} \mathrm{O}_{2}\right),(1 \mathrm{Mm})$ exposure on the contractile responses to $\mathrm{KCl}(30 \mathrm{mM})$ and prostaglandin $(\mathrm{PG}) \mathrm{F}_{2 \alpha}\left(3 \times 10^{-6} \mathrm{M}\right)$ in canine basilar (left) and mesenteric (right) arteries. The contractile response to each vasoconstrictor is expressed as a percentage of that obtained before $\mathrm{H}_{2} \mathrm{O}_{2}$ exposure. $\mathrm{H}_{2} \mathrm{O}_{2}$ exposure significantly inhibited the contractile responses to $\mathrm{KCl}$ and $\mathrm{PGF}_{2 \alpha}$ in basilar arteries, but not in mesenteric arteries $(P<0.01)$. Simultaneous exposure to halothane $(2 \%)$ did not affect $\mathrm{H}_{2} \mathrm{O}_{2}$-induced attenuation of the contractile responses to these constrictors.

7). In contrast to the basilar artery, $\mathrm{H}_{2} \mathrm{O}_{2}$ exposure did not affect the contractile responses to $\mathrm{KCl}$ and $\mathrm{PGF}_{2 \alpha}$ in mesenteric arteries $(n=7)$. Simultaneous exposure to halothane $(2 \%)$ did not affect the responsiveness to these vasoconstrictors in either artery $(n=4$, each).

\section{Histological examination of the endothelial cell layer by scanning electron microscopy}

The normal endothelial surface in control basilar artery demonstrated endothelial cells that were flat or spindle shaped, with a slight elevation in their central portions (Figure 4A). Exposure to $\mathrm{H}_{2} \mathrm{O}_{2}$ resulted in marked disruption of the endothelial layers. Endothelial cells were fractured and fragments of cellular debris appeared on the partially exposed basal lamina (Figure 4B). Simultaneous exposure to halothane $(2 \%)$ resulted in cellular appearances similar to that seen with $\mathrm{H}_{2} \mathrm{O}_{2}$ alone (Figure $4 \mathrm{C}$ ). The endothelial surface of control mesenteric arteries demonstrated a characteristic "cobblestone" appearance (Figure $4 \mathrm{D})$. Exposure to $\mathrm{H}_{2} \mathrm{O}_{2}$ exhibited no substantial changes on the endothelial surface (Figure 4E) Similar findings were observed with simultaneous exposure to halothane (Figure 4F). 
A

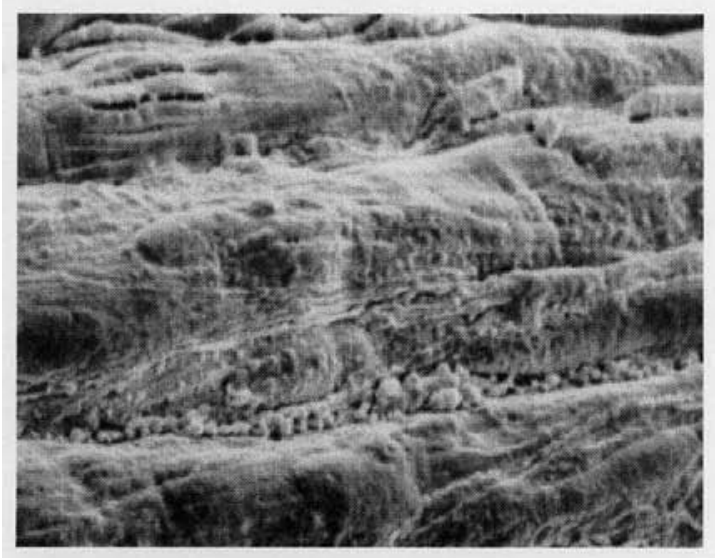

B

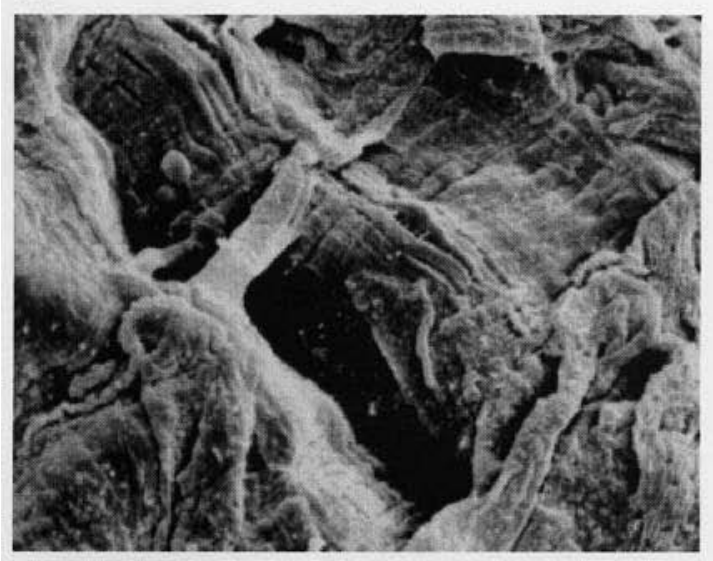

\section{C}

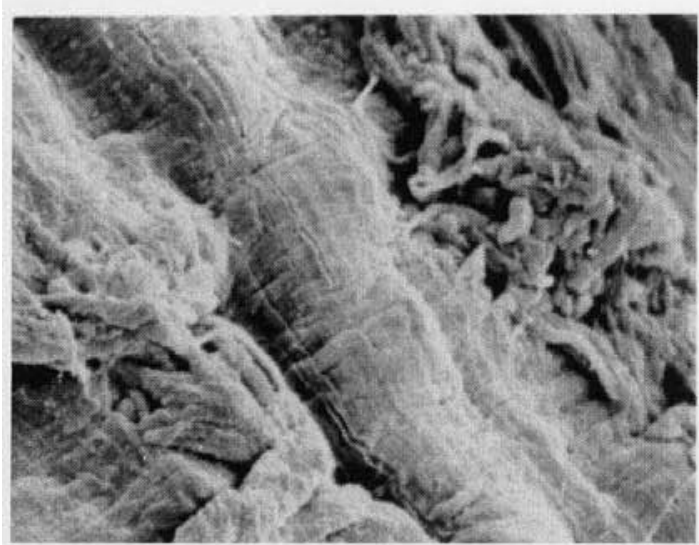

D

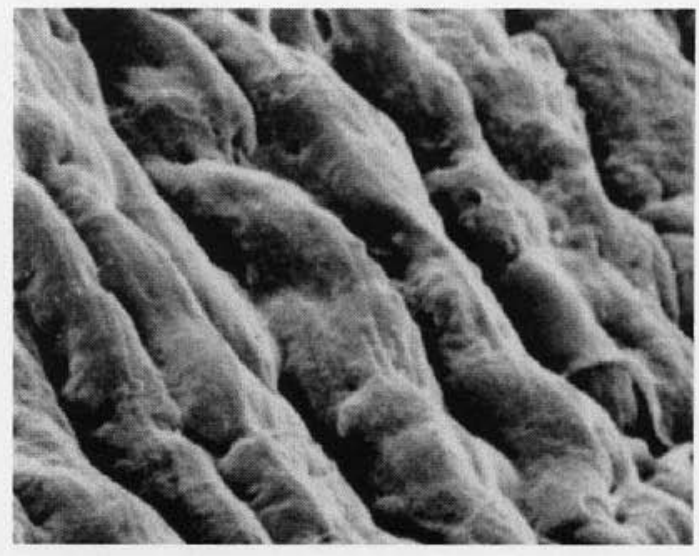

E

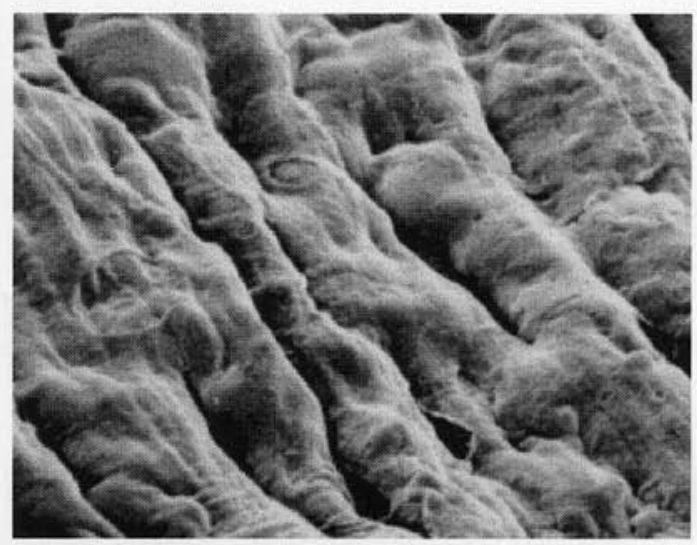

F

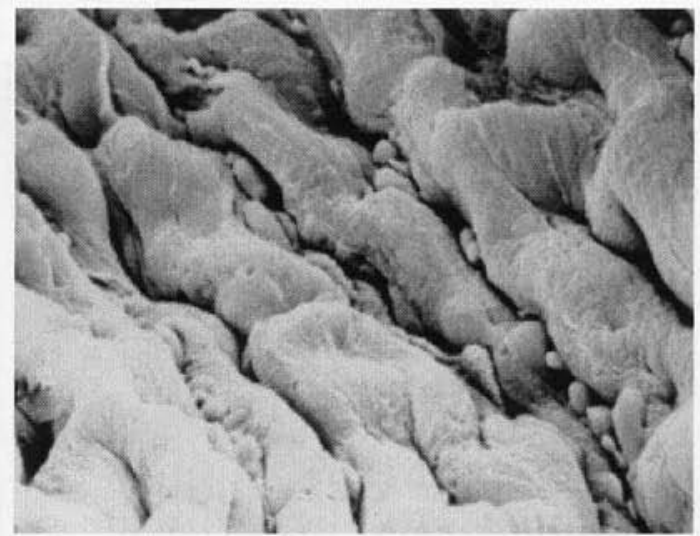

FIGURE 4 Photographs of the endothelium of canine basilar (A, B, C) and mesenteric (D, E, F) arteries. Scanning electron microscopic image showing the endothelial surface of normal basilar (A) and mesenteric (D) arteries, the endothelial surface of basilar (B) and mesenteric (E) arteries exposed to hydrogen peroxide $\left(\mathrm{H}_{2} \mathrm{O}_{2}\right),(1 \mathrm{mM})$, and the endothelial surface of basilar (C) and mesenteric (F) arteries simultaneously exposed to $\mathrm{H}_{2} \mathrm{O}_{2}(1 \mathrm{mM})$ and halothane (2\%). 


\section{Discussion}

The main findings of the study were as follows. Exposure to $\mathrm{H}_{2} \mathrm{O}_{2}$ markedly inhibited the endothelium-dependent vasorelaxant response to substance $\mathrm{P}$ in canine basilar arteries, but not in mesenteric arteries. Histological examination using scanning electron microscopy revealed disruption of the endothelial cell layer of basilar arteries. Exposure to $\mathrm{H}_{2} \mathrm{O}_{2}$ also attenuated the responsiveness to an endotheliumindependent vasodilator, SNP, as well as the contractile response to $\mathrm{KCl}$ and $\mathrm{PGF}_{2 \alpha}$ in basilar arteries. Halothane (2\%) exhibited no significant effects on the functional and morphological changes in endothelial cells in response to $\mathrm{H}_{2} \mathrm{O}_{2}$.

Reactive oxygen species generated during postischemic reperfusion mediate vascular damage, resulting in organ dysfunction. ${ }^{12,13} \mathrm{H}_{2} \mathrm{O}_{2}$, generated from superoxide anion with enzymatic or nonenzymatic dismutation, induces endothelial and vascular smooth muscle cell damage. ${ }^{5-11}$ This molecule is more stable and diffusible across the cell membrane than superoxide anion, and may therefore cause oxidative damage. ${ }^{4}$ $\mathrm{H}_{2} \mathrm{O}_{2}$ also reacts with superoxide anion to generate highly reactive hydroxyl radicals in the presence of ferrous ion. ${ }^{3}$ In the present study, exposure of basilar arteries to $\mathrm{H}_{2} \mathrm{O}_{2}$ resulted in loss of endotheliumdependent relaxation in response to substance $\mathrm{P}$ and marked disruption of the endothelial layer, supporting the cytotoxicity of $\mathrm{H}_{2} \mathrm{O}_{2}$ in endothelial cells. $1,2,7,9,11$ Exogenous $\mathrm{H}_{2} \mathrm{O}_{2}$ increases intracellular calcium and depletes cellular adenosine triphosphate, ${ }^{2,7,22}$ which may result in morphological changes in endothelial cells. ${ }^{7}$ Exposure to $\mathrm{H}_{2} \mathrm{O}_{2}$ also inhibited the endothelium-independent relaxation response to SNP and the contractile response to $\mathrm{KCl}$ and $\mathrm{PGF}_{2 \alpha}$ in basilar arteries, suggesting that vascular smooth muscle cells are also involved in $\mathrm{H}_{2} \mathrm{O}_{2}$-induced vascular injury. Similar to the present findings, $\mathrm{H}_{2} \mathrm{O}_{2}$-induced attenuation of the relaxation response to SNP has been reported in cat cerebral artery. ${ }^{5}$

The extent of the injury depends upon the concentration of $\mathrm{H}_{2} \mathrm{O}_{2}$ and duration of exposure. ${ }^{9}$ Eight minutes of exposure to $\mathrm{H}_{2} \mathrm{O}_{2}$ at a concentration of $1 \mathrm{mM}$ that was used in the present investigation appeared sufficient to cause endothelial injury in basilar, but not mesenteric arteries. In our preliminary study, more than ten minutes exposure suppressed the contractility of basilar artery too strongly to allow for pharmacological assessment of the endothelium-dependent relaxation, and less than $1 \mathrm{mM} \mathrm{H} \mathrm{H}_{2} \mathrm{O}_{2}$ did not induce any endothelial damage.

Heterogeneous susceptibility to oxidative stress has been reported in different types and sizes of arter- ies. ${ }^{14-17}$ From the present findings, the mesenteric artery was more resistant to oxidant stress than the basilar artery. There is extreme diversity in endothelial cell structure, architecture and physiology. ${ }^{23}$ The glutathione redox cycle is one of the most important endogenous antioxidant defense systems in endothelial cell, ${ }^{4}$ and has been shown to serve as a protecting system against $\mathrm{H}_{2} \mathrm{O}_{2}$-induced endothelial cell lysis. ${ }^{15}$ Differences in cellular stores of reduced glutathione may contribute to variations of susceptibility to oxidative injury in experimental models. ${ }^{15}$ Further, the endothelium of the cerebral artery has been recognized to exhibit heterogeneous pharmacological and histological properties, compared with that of other extracerebral arteries. ${ }^{19}$ For example, the endothelial layer of the cerebral artery forms tight junctions that act as a strong permeability barrier against some substances and plays an important role in maintaining the blood brain barrier. ${ }^{24}$ This unique property of cerebral arterial endothelium may be a target of reactive oxygen species. ${ }^{25}$

In addition to the endothelium, vascular smooth muscle cells of the basilar artery have been demonstrated to be more sensitive to $\mathrm{H}_{2} \mathrm{O}_{2}$ than those of the mesenteric artery in the present study. The muscular layer of the canine mesenteric artery is approximately twofold thicker than that of the cerebral artery, when comparing vessels with the same outer diameter size. ${ }^{18}$ It is possible that exogenously administered $\mathrm{H}_{2} \mathrm{O}_{2}$ could easily penetrate the thin muscular layer of the basilar artery from the luminal and adventitial surfaces, and result in extensive vascular smooth muscle dysfunction and damage. By contrast, certain portions of vascular smooth muscle of the mesenteric artery may remain intact against $\mathrm{H}_{2} \mathrm{O}_{2}$ injury because of the thick muscular layer. Susceptibility of the endothelium and the vascular smooth muscle of the cerebral artery to the oxidative stress may contribute to the unusual sensitivity to post-ischemic reperfusion injury of the brain. ${ }^{26}$

The effects of volatile anesthetics on oxidantinduced endothelial cell injury appear to be controversial. ${ }^{1,2}$ Shayevitz et al. demonstrated that halothane and isoflurane potentiated the cytotoxic effects of $\mathrm{H}_{2} \mathrm{O}_{2}$ on rat pulmonary endothelial cells in a concentrationdependent manner. ${ }^{1}$ Potentiation of oxidant-induced increases in permeability of pulmonary capillaries by halothane has also been reported ex vivo in a perfused rabbit lung model. ${ }^{27}$ However, Johnson et al. demonstrated that halothane, and to a lesser extent, isoflurane, protected against $\mathrm{H}_{2} \mathrm{O}_{2}$-induced injury in cultured human aortic endothelial cells by slowing the rate of cytosolic $\mathrm{Ca}^{2+}$ increase after $\mathrm{H}_{2} \mathrm{O}_{2}$ exposure. ${ }^{2}$ They also found that this protecting effect of volatile 
anesthetics was absent in pulmonary artery endothelial cells and concluded that the effects of anesthetics depended upon the vascular bed investigated and the concentration of anesthetics tested. ${ }^{2}$ Neither deteriorative nor ameliorative effects of halothane were observed in the present study. Since only $2 \%$ halothane was investigated in basilar and mesenteric arteries, we cannot exclude the possibility that higher or lower concentrations of halothane would have substantial effects on $\mathrm{H}_{2} \mathrm{O}_{2}$-induced vascular injury. Further, the results from the present study with halothane may not necessarily be extrapolated to other new volatile anesthetics, such as sevoflurane and desflurane.

In summary, exposure to $\mathrm{H}_{2} \mathrm{O}_{2}$ induced both endothelial and vascular smooth muscle cell damage in basilar arteries, but not in mesenteric arteries. These findings suggest that the basilar artery is more susceptible to oxidative stress than the mesenteric artery. Halothane, at least at a concentration of $2 \%$, exhibits no significant influence on this injury.

\section{References}

1 Shayevitz JR, Varani J, Ward PA, Knight PR. Halothane and isoflurane increase pulmonary artery endothelial cell sensitivity to oxidant-mediated injury. Anesthesiology 1991; 74: 1067-77.

2 Johnson ME, Sill JC, Ubl CB, Halsey TJ, Gores GJ. Effects of volatile anesthetics on hydrogen peroxideinduced injury in aortic and pulmonary arterial endothelial cells. Anesthesiology 1996; 84: 103-16.

3 Halliwell B, Clement MV, Long LH. Hydrogen peroxide in the human body. FEBS Lett 2000; 486: 10-3.

$4 \mathrm{Li} J M$, Shah AM. Endothelial cell superoxide generation: regulation and relevance for cardiovascular pathophysiology. Am J Physiol Regul Integr Comp Physiol 2004; 287: R1014-30.

5 Wei EP, Kontos HA. $\mathrm{H}_{2} \mathrm{O}_{2}$ and endothelium-dependent cerebral arteriolar dilation. Hypertension 1990; 16: 162-9.

6 Marczin N, Ryan US, Catravas JD. Effects of oxidant stress on endothelium-derived relaxing factor-induced and nitrovasodilator-induced cGMP accumulation in vascular cells in culture. Circ Res 1992; 70: 326-40.

7 Hinshaw DB, Burger JM, Armstrong BC, Hyslop PA. Mechanism of endothelial cell shape change in oxidant injury. J Surg Res 1989; 46: 339-49.

8 Katusic ZS, Schugel J, Cosentino F, Vanhoutte PM. Endothelium-dependent contractions to oxygenderived free radicals in the canine basilar artery. Am J Physiol 1993; 264(3Pt2): H859-64.

9 Krautschick I, Krugmann J, Neuenfeld M. The effect of peroxides on the vascular endothelium of isolated pig aorta in vitro. Exp Toxic Pathol 1995; 47: 51-61.
10 Ward PA. Mechanisms of endothelial cell killing by $\mathrm{H}_{2} \mathrm{O}_{2}$ or products of activated neutrophils. Am J Med 1991; 91 (suppl 3C): 89S-94S.

11 Mebta JL, Lawson DL, Nicolini FA, Ross MH, Player $D W$. Effects of activated polymorphonuclear leukocytes on vascular smooth muscle tone. Am J Physiol 1991; 26l(2Pt2): H327-34.

12 Traystman RJ, Kirsch JR, Koebler RC. Oxygen radical mechanisms of brain injury following ischemia and reperfusion. J Appl Physiol 1991; 71: 1185-95.

13 Sellke FW, Shafique T, Ely DL, Weintraub RM. Coronary endothelial injury after cardiopulmonary bypass and ischemic cardioplegia is mediated by oxygen-derived free radicals. Circulation 1993; 88(part 2): 395-400.

14 Vercellotti GM, Dobson M, Schorer AE, Moldow CF. Endothelial cell heterogeneity: antioxidant profiles determine vulnerability to oxidant injury. Proc Soc Exp Biol Med 1988; 187: 181-9.

15 Harlan JM, Levine JD, Callahan KS, Schwartz BR, Harker LA. Glutathione redox cycle protects cultured endothelial cells against lysis by extracellularly generated hydrogen peroxide. J Clin Invest 1984; 73: 706-13.

16 Lawson DL, Mehta JL, Nichols WW, Mehta P, Donnelly $W H$. Superoxide radical-mediated endothelial injury and vasoconstriction of rat thoracic aortic rings. J Lab Clin Med 1990; 115: 541-8.

17 Wei EP, Christman CW, Kontos HA, Povlishock JT. Effects of oxygen radicals on cerebral arterioles. Am J Physiol 1985; 248(2Pt2): H157-62.

18 Toda N, Hatano $\Upsilon$, Hayashi S. Modifications by stretches of the mechanical response of isolated cerebral and extracerebral arteries to vasoactive agents. Pflügers Arch 1978; 374: 73-7.

19 Nakagomi T, Hongo K, Kassell NF, et al. Pharmacological comparison of endothelium-dependent relaxation in isolated cerebral and extracerebral arteries. J Neurosurg 1988; 69: 580-7.

20 Engelhardt B. Development of the blood-brain barrier. Cell Tissue Res 2003; 314: 119-29.

21 ramamoto $M$, Hatano $\Upsilon$, Ogawa K, Iranami $H$, Tajima T. Halothane and isoflurane attenuate the relaxant response to nonadrenergic and noncholinergic nerve stimulation of isolated canine cerebral arteries. Anesth Analg 1998; 86: 552-6.

22 Yang $Z W$, Zheng $T$, Wang J, Zhang A, Altura BT, Altura $B M$. Hydrogen peroxide induces contraction and raises $\left[\mathrm{Ca}^{2+}\right]$ in canine cerebral arterial smooth muscle: participation of cellular signaling pathways. Naunyn Schmiedebergs Arch Pharmacol 1999; 360: 646-53.

23 Chi JT, Chang HY, Haraldsen G, et al. Endothelial cell diversity revealed by global expression profiling. Proc Natl Acad Sci 2003; 100: 10623-8. 
24 Nag S. Morphology and molecular properties of cellular components of normal cerebral vessels. Methods Mol Med 2003; 89: 3-36.

25 Van $\operatorname{der}$ Goes A, Wouters D, Van der Pol SM, et al. Reactive oxygen species enhance the migration of monocytes across the blood-brain barrier in vitro. FASEB J 2001; 15: 1852-4.

26 Grammas P, Lin GJ, Wood K, Floyd RA. Anoxia/reoxygenation induces hydroxyl free radical formation in brain microvessels. Free Radic Biol Med 1993; 14: $553-7$.

27 Shayevitz JR, Johnson KJ, Knight PR. Halothane-oxidant interactions in the ex vivo perfused rabbit lung. Anesthesiology 1993; 79: 129-38. 